\title{
PENGARUH PEMBELAJARAN MATA KULIAH KEWIRAUSAHAAN TERHADAP INTENSI KEWIRAUSAHAAN
}

\author{
Umi Choiriyah \\ Department of Management FEB UMM \\ Email:
}

\begin{abstract}
The research purpose of this study is to analyze the influence of entrepreneurship course on entrepreneurial intention. A simple linear regression was use as a statistical tool. The research used 85 of college students as a respondent. The result shows that entrepreneurship course has a positive significant effect on entrepreneurial intention. The recomendation is educational institutions should be facilitate entrepreneurship activities space in campus.
\end{abstract}

Keywords: Learning Entrepreneurship Courses, Entrepreneurship Intention

\section{PENDAHULUAN}

Era globalisasi saat ini jumlah perguruan tinggi cukup pesat khususnya di kota Malang sebagai kota pendidikan, selain dampak positif yang diperoleh ada juga kelemahannya yaitu meningkatnya jumlah pengangguran terdidik di setiap tahunnya.

Sarwono Nursito dan Arif Julianto (2013) mengemukakan, perbandingan lapangan kerja saat ini dengan jumlah pencari kerja tidak seimbang dibuktikan dengan tabel berikut ini

$\begin{array}{lr}\text { Tindakan yang } & \text { dilakukan } \\ \text { untuk menanggulangi } & \text { angka }\end{array}$ pengangguran terdidik adalah dengan menciptakan lapangan pekerjaan sendiri atau biasa disebut dengan profesi wirausaha, tentunya hal ini harus disertai dorongan dan kontribusi dari pihak pemerintah sebagai penanggung jawab yang berkewajiban atas penyelenggaraan proses pendidikan terkait dengan upaya peningkatan kualitas SDM agar tidak menjadi beban moral suatu negara.

Jiwa wirausaha dapat dibentuk pada diri seseorang melalui peran pendidikan. Lembaga pendidikan membagi kedalam dua kategori yaitu pendidikan informal seperti mengikuti lokakarya, seminar, bergabung dalam komunitas bisnis dan lain sebagainya serta pendidikan formal yang diberlakukan di lembaga pendidikan adalah dengan memberikan mata kuliah kewirausahaan.

Pembelajaran dirancang untuk membantu seseorang mempelajari suatu kemampuan dan atau nilai baru dalam hal ini adalah mahasiswa harus belajar kewirausahaan sebagai bagian didalam pembentukan potensi diri mahasiswa tehadap jiwa berwirausaha. Obyek penelitian ini yaitu meliputi beberapa universitas yang ada di Malang yaitu : Universitas Negeri Malang, Universitas Brawijaya, dan Universitas Islam Negeri Maulana Malik Ibrahim 
Malang.

Tabel 1. Data Mahasiswa

Manajemen yang telah menempuh

Mata kuliah Kewirausahaan Tahun 2011-2013

\begin{tabular}{lll}
\hline Universitas & Jumlah & Semester \\
\hline UM & 98 & 3 dan7 \\
& Mahasiswa & \\
UIN & 150 & 7 \\
& Mahasiswa & \\
UB & 338 & 3 \\
& Mahasiswa \\
Jumlah & 586 & \\
& Mahasiswa \\
\hline
\end{tabular}

Kondisi dilapangan yang terjadi untuk Universitas Negeri Malang dan Universitas Islam Negeri Malang mata kuliah kewirausahaan sebagai mata kuliah pilihan yang pada dasarnya ilmu kewirausahaan mempunyai peranan penting sebagai bekal terjun di masyarakat, sedangkan Universitas Brawijaya telah menjadikan mata kuliah kewirausahaan sebagai mata kuliah wajib ditempuh oleh mahasiswa, namun proses pembelajaran yang dilakukan dirasa masih belum optimal terbukti bagi sebagian mahasiswa, proses pembelajaran ini hanya merupakan aktivitas yang dilakukan untuk melengkapi nilai semata.

Pengukuran pembelajaran kewirausahaan yang dilakukan menggunakan teori Purnomo (2005) antara lain relavansi materi kewirausahaan dengan realitas kehidupan sehari-hari, kesesuaian proses pembelajaran kewirausahaan dengan minat mahasiswa, ketercapaian tujuan pembelajaran kewirausahaan, kesesuaian media yang digunakan dalam proses pembelajaran kewirausahaan, dan ketercukupan waktu yang disediakan untuk proses pembelajaran kewirausahaan. Program pendidikan formal dalam hal ini pembelajaran mata kuliah kewirausahaan seharusnya mendapatkan respon yang lebih baik dari mahasiswa agar lebih berhasil kedepannya. Khususnya, bagi mahasiswa jurusan manajemen yang pada dasarnya merupakan seorang calon wirausaha, ilmu yang didapat mahasiswa manajemen seperti mengenal peluang usaha, meningkatkan kreativitas atau ide, mengelola keuangan melakukan pemasaran atau penjualan, mengelola sumber daya manusia namun konsep dasar kewirausahaan tersebut belum diaplikasikan oleh mahasiswa, terlihat dari mayoritas mahasiswa masih sibuk melamar pekerjaan. Maka, disimpulkan Intensi berwirausaha dikalangan mahasiswa masih rendah. Intensi bermakna niat. Intensi juga menandakan bagaimana upaya seseorang mencoba dan berencana untuk menampilkan perilaku tertentu dalam hal ini perubahan seseorang setelah mendapatkan mata kuliah kewirausahaan dapat terlihat dengan intensi berwirausaha mahasiswa yang mengarah pada perilaku wirausaha seperti lebih memilih profesi wirausaha sebagai tujuan karir, berniat merealisasikan usaha 1-5 tahun yang akan datang, memiliki pemikiran yang serius mengenai bagaimana memulai usaha yang pada intinya mengarah pada perilaku bisnis.

Pembekalan yang cukup dari proses pembelajaran kewirausahaan diharapkan mampu disampaikan secara optimal sehingga dapat merubah pola pikir mahasiswa yang cenderung berkeinginan menjadi seorang pekerja, Jika hal tersebut 
dilakukan dapat membantu roda perekonomian untuk pribadi, keluarga maupun negaranya.

\section{TINJAUAN PUSTAKA}

Pembelajaran dirancang untuk membantu seseorang mempelajari suatu kemampuan dan atau nilai baru dalam hal ini adalah belajar kewirausahaan. Eman Suherman (2008) mengatakan bahwa pola pembelajaran kewirausahaan minimal mengandung empat unsur sebagai berikut : Pemikiran pengetahuan tentang nilai-nilai, semangat, jiwa, sikap dan perilaku, Perasaaan, yang diisi oleh penanaman empatisme sosial ekonomi, Keterampilan, Kesehatan fisik, mental dan sosial. Penelitian ini menggunakan teori Purnomo (2005) sebagai pengukuran pembelajaran kewirausahaan diantaranya Relavansi materi kewirausahaan dengan realitas kehidupan sehari-hari, Kesesuaian proses pembelajaran kewirausahaan dengan minat, Ketercapaian tujuan pembelajaran Kesesuaian media yang digunakan dalam proses pembelajaran kewirausahaan, dan Ketercukupan waktu yang disediakan untuk proses pembelajaran kewirausahaan. Pembelajaran kewirausahaan yang diberikan sebagai upaya pembentukan jiwa berwirausaha dikalangan mahasiswa, hasil yang dicapai dapat ditunjukan melalui perilaku tertentu yang dijembatani dengan melihat intensi seseorang. Intensi secara harfiah bermakna niat. Pembentukan intensi pada diri seseorang terlihat dalam suatu perilaku tertentu. Intensi juga menandakan bagaimana upaya seseorang mencoba dan berencana untuk menampilkan perilaku tertentu. Faktor yang mempengaruhi intensi kewirausahaan menurut Nurul dan Rokhima (2008) yaitu Faktor Kepribadian, faktor lingkungan dan faktor Demografi yang meliputi gender, umur, latar belakang pendidikan, pekerjaan orang tua, dan pengalaman kerja. Meningkatkan intensi berwirausaha menjadi salah satu tujuan utama dari program pendidikan kewirausahaan pembelajaran formal maupun non formal yang pada umumnya hal ini sering digunakan sebagai ukuran hasil atau evaluasi dalam kontribusi program pembelajaran kewirausahaan terhadap niat berwirausaha. seperti lebih memilih profesi wirausaha sebagai tujuan karir, berniat merealisasikan usaha 1-5 tahun yang akan datang, memiliki pemikiran yang serius mengenai bagaimana memulai usaha.

\begin{tabular}{|c|c|}
\hline 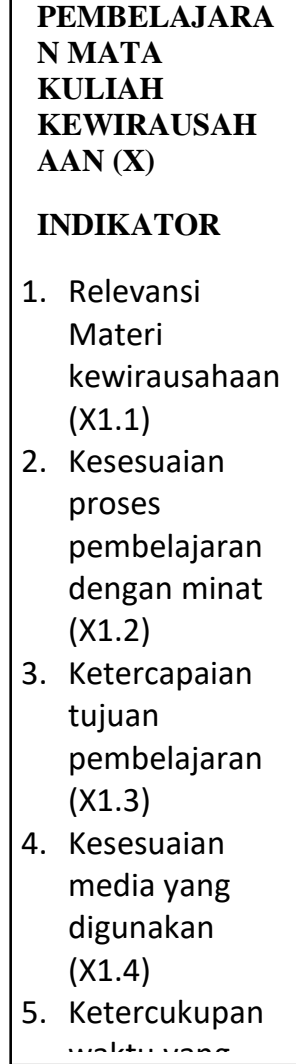 & $\begin{array}{l}\text { 1. Lebih memilih } \\
\text { wirausaha } \\
\text { sebagai tujuan } \\
\text { karir (Y1.1) } \\
\text { 2. berniat } \\
\text { merealisasikan } \\
\text { usaha 1-5 tahun } \\
\text { yang akan } \\
\text { datang (Y1.2) } \\
\text { 3. memiliki } \\
\text { pemikiran yang } \\
\text { serius } \\
\text { mengenai } \\
\text { bagaimana } \\
\text { memulai usaha } \\
\text { (Y1.3) }\end{array}$ \\
\hline
\end{tabular}

Gambar 1. Kerangka pikir Penelitian 
Berdasarkan kerangka pikir diatas terlihat bahwa rangkaian proses pembelajaran mata kuliah kewirausahaan (berkenaan dengan relevansi materi kewirausahaan, kesesuaian proses pembelajaran dengan minat, ketercapaian tujuan pembelajaran, kesesuaian media yang digunakan dan ketercukupan waktu yang disediakan) akan memberikan pengaruh terhadap intensi kewirausahaan mahasiswa. Artinya, jika tenaga pendidik dapat menyesuaikan pembelajaran mata kuliah ini dengan minat mahasiswa, relevansi materi yang diberikan disesuaikan dengan kehidupan seharihari, adanya media yang mendukung proses pembelajaran, maka pembelajaran mata kuliah kewirausahaan dapat diberikan secara optimal oleh tenaga pengajar dan dapat membentuk intensi berwirausaha lingkup mahasiswa.

\section{METODE PENELITIAN}

Jenis penelitian yang dilakukan ini bersifat penelitian survey, lokasi penelitian ini dilakukan di 3 Universitas negeri yang berbeda di Kota Malang yakni; Universitas Negeri Malang berlokasi di jalan Semarang no.5 Malang Jatim, Universitas Brawijaya berada di jalan Veteran Malang Jatim, sedangkan Universitas Islam Negeri Maulana Malik Ibrahim Malang berada di Jalan Gajayana no.50 Malang Jatim.

Indikator yang digunakan adalah: Relavansi materi kewirausahaan dengan realitas kehidupan sehari-hari bahwa materi yang diberikan merupakan dasar kewirausahaan dan menghubungkan langsung materi dengan keseharian atau rill dilapangan, Kesesuaian proses pembelajaran kewirausahaan dengan minat, metode pembelajaran yang dilakukan tidak monoton dan dirasa efektif oleh mahasiswa, Ketercapaian tujuan pembelajaran kewirausahaan, tenaga pendidik menginformasikan tujuan dari pembelajaran yang dilakukan agar mahasiswa memahami inti dari mata kuliah kewirausahaan, Kesesuaian media yang digunakan dalam proses pembelajaran kewirausahaan dengan adanya fasilitas dan media yang memadai maka, pembelajaran kewirausahaan bisa dijalankan lebih optimal, Ketercukupan waktu yang disediakan untuk proses pembelajaran kewirausahaan, pembelajaran non formal juga dibutuhkan dalam mengembangkan potensi kewirausahaan selain mempelajari mata kuliah kewirausahaan di dalam ruang kelas.

\begin{tabular}{lcr}
\multicolumn{2}{c}{ Variabel } & Intensi \\
kewirausahaan bagaimana upaya \\
seseorang untuk mencoba dan \\
berencana untuk \\
Indikator berwirausaha. \\
digunakan
\end{tabular} diantaranya: Lebih memilih wirausaha sebagai tujuan karir yaitu berencana terjun kedunia bisnis atau memilih karir menjadi wirausaha, Berniat merealisasikan usaha 1-5 tahun yang akan datang memiliki niatan dan mengupayakan agar 1-5 tahun yang akan datang dapat menjadi pengusaha, Memiliki pemikiran yang serius mengenai bagaimana memulai usaha berusaha merencanakan dengan matang dan mulai membuat strategi bisnis untuk memulai usaha. Data dan sumber data yang digunakan dalam penelitian ini adalah data kualitatif berupa data profil perguruan tinggi, sistem akademik dan data kuantitatif berupa data jumlah mahasiswa yang 
telah menempuh pendidikan kewirausahaan tahun 2011-2013. Sumber data yang digunakan yakni data primer dan data sekunder. Metode pengumpulan data dalam penelitian ini menggunakan quisioner, wawancara dan dokumentasi.

Teknik sampling yang dilakukan menggunakan purposive sampling yaitu teknik penentuan sampel dengan kriteria tertentu. Dalam penelitian ini sampel yang digunakan berjumlah 85 responden pada mahasiswa manajemen yang telah menempuh mata kuliah kewirausahaan semester ganjil universitas negeri di kota malang.

Pengukuran variabel menggunakan skala likert. Teknik pengujian instrument yang dilakukan adalah uji validitas dan uji reabilitas, sedangkan teknik analisis data dan hipotesis yang dilakukan setelah peneliti mengumpulkan semua data adalah Rentang skala, regresi linier sederhana, koefisien determinasi dan uji t atau (uji parsial).

\section{HASIL DAN PEMBAHASAN}

Pembelajaran Mata kuliah kewirausahaan dinilai baik dan Intensi berwirausaha mahasiswa mahasiswa jurusan Manajamen Universitas Negeri di kota Malang juga dikategorikan tinggi terbukti dari uji validitas yang dilakukan menunjukkan hasil valid dan realibel.

Dari data diatas dapat disimpulkan bahwa semua instrumen variabel pembelajaran mata kuliah kewirausahaan valid, karena terbukti bahwa nilai koefisien lebih besar dari nilai kritik pada tingkat signifikan 5\%. Hasil yang didapatkan dari variabel pembelajaran mata kuliah kewirausahaan dengan menggunakan
Cronbach's Alpha sebesar 0,662 artinya semakin mendekati 1 menunjukkan makin reliabel.

Tabel 2. Uji Validitas dan Uji

Reabilitas Variabel Pembelajaran Mata Kuliah Kewirausahaan

\begin{tabular}{|c|c|c|c|}
\hline Hubungan & $\begin{array}{l}\text { r- } \\
\text { hitun }\end{array}$ & $\begin{array}{l}\mathrm{r}- \\
\text { tabel }\end{array}$ & Ket \\
\hline (X1.1) & $\begin{array}{l}\mathrm{g} \\
0,704\end{array}$ & 0,178 & Vali \\
\hline (X1.2) & 0,575 & 6 & $\mathrm{~d}$ \\
\hline (X1.3) & 0,728 & 0,178 & Vali \\
\hline (X1.4) & 0,657 & 6 & $\mathrm{~d}$ \\
\hline \multirow[t]{6}{*}{ (X1.5) } & 0,603 & 0,178 & Vali \\
\hline & & 6 & d \\
\hline & & 0,178 & Vali \\
\hline & & 6 & $\mathrm{~d}$ \\
\hline & & 0,178 & Vali \\
\hline & & 6 & $\mathrm{~d}$ \\
\hline Cronbach' & 0,662 & & Vali \\
\hline $\mathrm{S}$ & & & $d$ \\
\hline Alpha & & & \\
\hline
\end{tabular}

Pembelajaran mata kuliah kewirausahaan meliputi relevansi materi kewirausahaan, kesesuaian dengan minat, ketercapaian tujuan pembelajaran, kesesuaian media yang digunakan dalam proses pembelajaran, dan ketercukupan waktu yang disediakan untuk proses pembelajaran kewirausahaan.

Instrumen variabel intensi kewirausahaan juga dikatakan valid dan cronbach's Alpha sebesar 0,820 yang artinya reliabel, yang meliputi lebih memilih profesi wirausaha sebagai tujuan karir, berniat merealisasikan usaha 1-5 tahun yang akan datang, memiliki pemikiran yang serius mengenai bagaimana memulai usaha.

Karakteristik dalam penelitian ini terbagi dalam beberapa item diantaranya karakteristik pekerjaan 
orang tua yang memiliki presentase tertinggi yakni $36 \%$ berlatar belakang wirausaha sisanya berprofesi sebagai PNS, petani, swasta, BUMN. Adanya garis keturunan dan ruang lingkup sebagai wirausaha dapat memotivasi seseorang mulai sejak dini untuk terjun sebagai wirausaha, berdasarkan data responden keinginan setelah lulus data teringgi adalah keinginan menjadi pegawai swasta sebesar $41 \%$, selanjutnya banyak yang memilih untuk melanjutkan kuliah S2. Posisi yang menginginkan menjadi wirausaha berada di posisi ketiga dengan presentase sebesar $15 \%$ hal tersebut menunjukkan sebagian besar mahasiswa cenderung memiliki pola pikir sebagai pekerja.

Hasil rata-rata rentang skala variabel pembelajaran mata kuliah kewirausahaan diperoleh hasil sebesar 264,6 baik yang menunjukkan bahwa pembelajaran mata kuliah kewirausahaan yang diberikan oleh tenaga pendidik termasuk dalam kategori baik. Hasil baik menunjukkan bahwa selama ini responden merasakan pendididikan formal dalam hal ini pemberian materi mata kuliah kewirausahaan dianggap telah sesuai dengan minat mahasiswa. Indikator variabel pembelajaran mata kuliah kewirausahaan meliputi relavansi materi kewirausahaan dengan realitas kehidupan sehari-hari, kesesuaian proses pembelajaran kewirausahaan dengan minat siswa, ketercapaian tujuan pembelajaran kewirausahaan, kesesuaian media yang digunakan dalam proses pembelajaran kewirausahaan, dan ketercukupan waktu yang disediakan untuk proses pembelajaran kewirausahaan sedangkan variabel intensi kewirausahaan meliputi Lebih memilih wirausaha sebagai tujuan karir yaitu berencana terjun kedunia bisnis atau memilih karir menjadi wirausaha, Berniat merealisasikan usaha 1-5 tahun yang akan datang memiliki niatan dan mengupayakan agar 1-5 tahun yang akan datang dapat menjadi pengusaha, Memiliki pemikiran yang serius mengenai bagaimana memulai usaha berusaha merencanakan dengan matang dan mulai membuat strategi bisnis untuk memulai usaha. Hasil rata-rata rentang skala variabel intensi kewirausahaan diperoleh angka sebesar 252,3 yang menunjukkan bahwa intensi mahasiswa terhadap wirausaha masuk dalam kategori tinggi. Hasil tinggi bahwa mahasiswa menyukai dan berniat menggeluti bidang bisnis atau berwirausaha. Indikator Intensi kewirausahaaan meliputi lebih memilih profesi wirausaha sebagai tujuan karir, berniat merealisasikan usaha 1-5 tahun yang akan datang, memiliki pemikiran yang serius mengenai bagaimana memulai usaha.

Analisis data regresi linier sederhana digunakan untuk menghitung besarnya pengaruh antara variabel independen terhadap variabel dependen yaitu, pembelajaran mata kuliah kewirausahaan terhadap intensi kewirausahaan.

Variabel bebas pada penelitian ini adalah pembelajaran mata kuliah kewirausahaan dan variabel terikat dalam penelitian ini yaitu intensi kewirausahaan. dilakukan dengan program SPSS versi 20,0 for windows dengan tingkat kepercayaan yang digunakan sebesar $95 \%(\alpha=0,05)$. $\mathrm{Y}=5,792+0,230 \mathrm{x}$

Konstanta (a) sebesar $\quad 5,792$ menunjukkan besarnya nilai variabel Intensi kewirausahaaan (y) jika 
variabel bebasnya yaitu Pembelajaran mata kuliah kewirausahaan (x) dianggap nol, artinya jika tidak ada pengaruh dari mata kuliah kewirausahaan. Maka besarnya Intensi kewirausahaan mahasiswa Universitas Negeri di Kota Malang yaitu sebesar 5,792.

$b x=0,230$, Nilai koefisien regresi $b x$ menunjukkan jika variabel pembelajaran mata kuliah kewirausahaan meningkat lebih baik maka Intensi kewirausahaan akan meningkat sebesar 0,230, atau dengan kata lain setiap ada peningkatan pembelajaran kewirausahaan dalam penelitian ini yaitu relevansi materi kewirausahaan dengan realitas kehidupan sehari-hari, kesesuaian proses pembelajaran kewirausahaan dengan minat, ketercapaian tujuan pembelajaraan kewirausahaan, kesesuaian media yang digunakan dalam proses pembelajaran, dan ketercukupan waktu yang disediakan untuk proses pembelajaran kewirausahaan. Maka Intensi kewirausahaan juga akan meningkat dengan asumsi variabel bebas lainnya tetap. Dilihat dari tabel regresi linier sederhana nilai koefisien determinasi $\left(r^{2}\right)$ sebesar 0,061 atau $6,1 \%$ sedangkan sisanya sebesar $93,9 \%$ disebabkan oleh variabel lain di luar variabel penelitian

Dari hasil hitung diketahui t hitung antara X (Pembelajaran Mata Kuliah Kewirausahaan) dengan $\mathrm{Y}$ (Intensi Kewirausahaan) menunjukkan thitung $=2,312$. sedangkan t tabel $(\alpha=0.05)$ adalah sebesar 1,663, Maka thitung > ttabel yaitu 2,312>1,663 maka pengaruh $X$ (Pembelajaran Mata Kuliah Kewirausahaan) dengan Y (Intensi Kewirausahaan) adalah signifikan.
Umpan balik atau feedback yang didapat dari sebagian besar mahasiswa dilapangan (rill) masih banyak anggapan dari mahasiswa bahwa belajar kewirausahaan intinya "berdagang" skala kecil sehingga lebih memilih menjadi " pegawai" dan image disegani masyarakat ketimbang entrepreneurs, merasa masih amatir, takut pada ketidakpastian, tidak berani mengambil resiko, tidak ada modal, zona aman menjadi pekerja yang mendapatkan gaji tetap, serta banyaknya pertimbangan lain sehingga mahasiswa hanya menjadikan wirausaha sebatas profesi sampingan, atau sebagai pilihan terakhir setelah menjadi pekerja atau bahkan tidak berniat menjadi wirausaha.

\section{SIMPULAN}

Berdasarkan hasil penelitian dan pembahasan yang telah dilakukan maka dapat ditarik kesimpulan sebagai berikut: Pembelajaran mata kuliah kewirausahaan mahasiswa jurusan Manajemen Universitas Negeri di Kota Malang meliputi Universitas Negeri Malang, Universitas Brawijaya dan Universitas Islam Negeri Maulana Malik Ibrahim Malang masuk dalam kriteria baik terbukti dari hasil rata-rata rentang skala menunjukkan nilai skor variabel sebesar 264,6. Hasil perhitungan tersebut meliputi indikator sebagai berikut : relevansi materi kewirausahaan dengan realitas kehidupan sehari-hari (X1.1) memperoleh skor 279 dengan kategori sangat baik, kesesuaian proses pembelajaran kewirausahaan dengan minat mahasiswa (X1.2) mendapatkan penilaian 265 dengan kategori baik, ketercapaian tujuan pembelajaran 
kewirausahaan (X1.3) mendapatkan skor 281 dengan kriteria sangat baik, kesesuaian media yang digunakan dalam proses pembelajaran (X1.4) dan ketercukupan waktu yang disediakan untuk proses pembelajaran kewirausahaan (X1.5) memperoleh skor yang sama sebesar 249 dengan kriteria baik. Variabel Intensi Kewirausahaan yaitu lebih memilih karir wirausaha Y(1.1) mendapatkan nilai sebesar 254 masuk dalam kriteria intensi kewirausahan tinggi, respon mahasiswa mengenai berniat merealisasikan usaha 1-5 tahun yang akan datang $\mathrm{Y}(1.2)$ diperoleh nilai sebesar 246 juga masuk dalam kriteria penilaian intensi kewirausahaan tinggi. Hasil tersebut dapat membuktikan kesungguhan niat berwirausaha dan memiliki pemikiran yang serius mengenai bagaimana memulai usaha $\mathrm{Y}(1.3)$ diperoleh nilai sebesar 257 juga dikategorikan tinggi. Maka, disimpulkan intensi kewirausahaan dinilai tinggi sebesar 252,3, Perhitungan dalam penelitian ini menggunakan analisis regresi linier sederhana terdapat pengaruh yang signifikasi antara Pembelajaran mata kuliah kewirausahaan terhadap Intensi kewirausahaan mahasiswa jurusan manajemen Universitas Negeri di Kota Malang, yaitu sebesar 0,230 sedangkan perhitungan berdasarkan hasil uji distribusi t, didapat $\mathrm{t}$ hitung $>\mathrm{t}$ tabel yaitu 2,312>1,663 maka pengaruh $\mathrm{X}$ (Pembelajaran mata kuliah kewirausahaan Kewirausahaan) dengan Y (Intensi kewirausahaan) adalah signifikan. Hal ini berarti $\mathrm{H}_{0}$ ditolak dan $\mathrm{H}_{1}$ diterima. Diharapkan pihak lembaga pendidikan, tenaga pendidik ataupun pihak-pihak yang terkait bekerjasama meningkatkan fasilitas dan media yang digunakan dalam proses pembelajaran kewirausahaan tidak hanya sebatas pembelajaran formal, mengikuti mata kuliah kewirausahaan dalam lingkup ruang kelas saja namun juga diimbangi dengan aplikasi langsung, observasi, memberikan sarana yang menunjang seperti area bisnis mahasiswa atau memberikan skill secara pembelajaran informal serta mengevaluasi metode pembelajaran saat ini, dan disesuaikan dengan minat mahasiswa.

\section{DAFTAR PUSTAKA}

Indiarti, N. Dan Rokhima R. 2008, Intensi Kewirausahaan Mahasiswa: Studi Perbandingan Antara Indonesia, Jepang dan Norwegia, Jurnal Ekonomika dan Bisnis Indonesia, Vol. 23, No. 4.

Nursito, Sarwono dan Nugroho Arif, J. S. 2013, Analisis Pengaruh Interaksi Pengetahuan Kewirausahaan Dan Efikasi Diri Terhadap Intensi Kewirausahaan (Staf Pengajar Universitas Widya Dharma Klaten)

Purnomo, B H. 2005, Menumbuhkan Semangat

Kewirausahaan.Yogyakarta: laksbang pressindo

Suherman, $\quad$ Eman.2008.Desain Pembelajaran

Kewirausahaan. Bandung: CV Alfabeta. 